\title{
Skin Response Data Collection Date Time
}

National Cancer Institute

\section{Source}

National Cancer Institute. Skin Response Data Collection Date Time. NCI Thesaurus.

Code C117692.

The date and time skin response data was collected. 